Acta Universitatis Nicolai Copernici • Pedagogika XXXI/2015

Nauki Humanistyczno-Społeczne • Zeszyt 426

DOI: http://dx.doi.org/10.12775/AUNC_PED.2015.012

\author{
Lidia Anna Wiśniewska \\ Wydział Nauk Pedagogicznych \\ Uniwersytet Mikołaja Kopernika w Toruniu
}

\title{
Bessel van der Kolk, The body keeps the score. Brain, mind and body in the healing of trauma,
}

New York 2015, ss. 443

Droblem traumy jest obecny w psychologii i naukach pokrewnych L od wielu lat, jednak wraz z postępem wiedzy na temat roli urazu psychicznego w powstawaniu zaburzeń psychicznych czy konsekwencji takiego urazu dla psychospołecznego funkcjonowania osoby coraz więcej uwagi poświęca się tej tematyce. Na rynku wydawniczym obecnych jest więc wiele pozycji poruszających problematykę psychotraumatologii i podejmujących naukową dyskusję na temat tego, czym jest trauma, jak wpływa na funkcjonowanie osoby, czy też jakie symptomy mogą wskazywać na to, że osoba cierpi na zespół stresu pourazowe$\mathrm{go}^{1}$. Wiedza nie tylko z psychologii, ale również $\mathrm{z}$ neuronauki $-\mathrm{w}$ tym z badań nad neuroobrazowaniem mózgu - przyczynia się do coraz lepszego rozumienia druzgocącej roli traumy w życiu osoby i szukania efektywniejszych sposobów pomocy.

1 Można, obok wielu innych pozycji, wymienić tutaj m.in.: B. Borys, Psychiczne następstwa wydarzeń i sytuacji ekstremalnych. Ich ocena oraz formy pomocy, „Annales Academiae Medicae Gedanensis”, T. XXXII. Suplement, Gdańsk 2012; Konsekwencje psychiczne traumy: uwarunkowania i terapia, pod red. J. Strelau, B. Zawadzkiego, M. Kaczmarek, Warszawa 2009; M. Lis-Turlejska, Traumatyczne zdarzenia i ich skutki psychiczne, Warszawa 2005. 
Wśród wielu pozycji na szczególną uwagę zasługuje książką pt. The body keeps the score. Brain, mind and body in the healing of trauma, której autor - Bessel van der Kolk - od wielu lat bada uraz psychiczny i pracuje z pacjentami, którzy zmagają się z traumą. Ta naukowa pozycja pełna odniesień do wielu badań z ostatnich dziesięcioleci - w tym do badań najnowszych - jest tak naprawdę fascynującą opowieścią o człowieku. Autor z głębokim szacunkiem dla osób, które doznały urazów psychicznych - a więc do osób, które przyczyniły się do rozwoju wiedzy z tej dziedziny - pokazuje, jak druzgocąca jest trauma: opisuje, jak niekiedy dosłownie w kilka chwil burzy dotychczasowe życie, jak zabiera nadzieję na poprawę, bo ciągle na nowo jest przeżywana, gdy człowiek wraca w snach i wspomnieniach, „wizjach” do tego, co się wydarzyło (flashback) za dnia. Trauma sprawia, że życie traci sens i nie jest już „warte życia”, a ponieważ jest zakodowana na poziomie niewerbalnym (np. osoby pamiętają zapachy, odgłosy), często nie może zostać opowiedziana, a przez to trudniej z nią sobie poradzić ${ }^{2}$. Van der Kolk zwraca uwagę, że uporanie się z nią jest możliwe, ale nie obiecuje natychmiastowej poprawy. Pokazuje on bowiem, że zdrowienie jest procesem, który może odbywać się różnymi drogami ${ }^{3}$. Niektóre z nich są mniej, inne bardziej efektywne, ale każda z nich wymaga czasu i cierpliwości. Nie ma bowiem magicznego lekarstwa na traumę, a psychofarmakologia - mimo wielu zasług w dziedzinie leczenia zaburzeń i chorób psychicznych - powinna być jedynie formą wspierającą, a nie dominującą w pracy z osobami po urazach ${ }^{4}$.

Książka składa się z pięciu części. W pierwszej z nich autor porusza problem rozumienia traumy na przestrzeni ostatnich dziesięcioleci - i szczególnej roli weteranów wojen (głównie wojny w Wietnamie) $\mathrm{w}$ procesie zdobywania wiedzy z tej dziedziny. To ich historie - pełne problemów z alkoholem, przemocą czy wybuchów złości - przyczyniły się do zrozumienia, jak zachowanie i funkcjonowanie w codziennym życiu zmienia się z uwagi na doznany uraz psychiczny. Ostatni

2 B. Van der Kolk, The body keeps the score: brain, mind, and the body in the healing of trauma, New York 2014, s. 44-47.

3 Por. tamże, s. 3.

4 Tamże, s. 36-38. 
rozdział części drugiej i cała część trzecia poświęcone są głównie neurobiologii (do której autor odwołuje się wielokrotnie także w innych częściach książki). Van der Kolk pokazuje, w jaki sposób najnowsze zdobycze technologiczne, m.in. funkcjonalny rezonans magnetyczny (fMRI), pozwalają na lepsze i dokładniejsze poznanie funkcjonowania mózgu osoby, która doświadczyła urazu psychicznego. Autor w przystępny sposób opowiada o zmianach, które zachodzą pod wpływem traumy. Zwraca on jednocześnie uwagę, że zdobywanie wiedzy z tej dziedziny jest procesem, a odpowiedź na jedno pytanie prowadzi do zadawania kolejnych. Jedno z bardziej przerażających odkryć pokazuje, że nawet wiele lat po wydarzeniu traumatycznym osoba może je nadal przeżywać (także na poziomie doznań biologicznych), jakby działo się ono „tu i teraz”. Oznacza to, że nie staje się ono częścią przeszłości, ale czymś, co ciągle trwa zapisane w doznaniach płynących z ciała. Osoby, które doświadczyły traumy, są niejednokrotnie zdania, że brak możliwości uwolnienia się od niej jest doświadczeniem bardziej niszczącym i druzgocącym niż sam uraz. Część trzecia książki poświęcona jest negatywnym doświadczeniom z okresu dzieciństwa i tym, jak m.in. różne rodzaje przemocy czy zaniedbania zmieniają funkcjonowanie najmłodszych. Autor odwołuje się do badań nad przywiązaniem (cytuje m.in. Johna Bowlby'ego i Donalda Winnicotta) i zwraca uwagę na długofalowe skutki rozwoju pozabezpiecznych form przywiązania. Dzieci, które doznały urazów psychicznych (np. związanych z brakiem zapewnienie poczucia bezpieczeństwa, przemocą), interpretują pokazywane im obrazki (np. kobietę $\mathrm{w}$ ciąży, rodzinę przy pracy) ${ }^{5} \mathrm{w}$ zupełnie odmienny sposób od dzieci, które wychowywały się w domach pełnych miłości i troski. Obie grupy opowiadają historie odbijające ich doświadczenia - w pierwszej $\mathrm{z}$ nich będzie więc dominować niepewność, lęk i agresja (np. zwracanie uwagi, że jeden z członków rodziny zaraz zrobi krzywdę drugiemu), a w drugiej - miłość i spokój (np. opowieści o wzajemnej pomocy). Trauma wczesnodziecięca zmienia więc sposób odbierania świata - staje się on miejscem niebezpiecznym, w którym inni ludzie są źli i nastawieni na wyrządzenie krzywdy. W rozdziale czwartym Van der

\footnotetext{
5 Tamże, s. 106-109.
} 
Kolk opisuje, jak trauma jest pamiętana i czemu często jest wypierana z pamięci nawet na wiele lat, a potem wraca przypomniana przez słowo, gest, zapach czy inne wydarzenie. Jednak często wspomnienia związane z urazem są niepełne i fragmentaryczne, co nie oznacza, że są nieprawdziwe. Ostatnia część książki opisuje „drogi do zdrowienia". Autor podkreśla, że nie da się wymazać urazu, nie da się cofnąć czasu i sprawić, by pewne wydarzenia nie miały miejsca ${ }^{6}$. Można jednak pracować z tym, jaki wpływ trauma wywarła na życie, np. z ciągłym poczuciem lęku, utratą kontroli, koszmarami czy problemami z koncentracją. Van der Kolk podkreśla, że celem terapii ma być przywrócenie osobie panowania nad jej umysłem i ciałem. Może on zostać osiągnięty różnymi sposobami - zarówno poprzez pracę w gabinecie terapeutycznym, jak i np. na sali ćwiczeń. Wiele metod może być ze sobą integrowanych.

Reasumując, Van der Kolk zaprasza czytelnika - zarówno profesjonalistę (lekarza, psychologa, terapeutę, pedagoga), jak i laika (być może osobę dotkniętą traumą lub jej rodzinę) w niezwykłą podróż. Krok po kroku autor odkrywa to, czego on i jego koledzy nauczyli się o urazie psychicznym, pokazując jednocześnie to, czego jeszcze nie wiadomo. Książka napisana jest przystępnym językiem, co nie oznacza, że jest łatwa w odbiorze, porusza bowiem kwestie trudne i obciążające. Jest jednocześnie swoistym kompendium wiedzy o traumie i sposobach pomocy - a przede wszystkim jest świadectwem siły człowieka: zarówno tego, który zmaga się z urazem, jak i naukowców poszukujących sposobów pomocy. Van der Kolk pokazuje jeszcze jedną ważną rzecz - wiedza powinna być użyteczna, powinna pomóc człowiekowi, a jej zdobywanie jest procesem. Aby osiągnąć taką refleksję, taką biegłość w danej tematyce, jaką prezentuje autor, trzeba wielu lat praktyki i badań nad danym zagadnieniem.

6 Tamże, s. 203-204. 